\title{
Materiality of Edible Film Packaging in Muscle Foods: A Worthwhile Conception
}

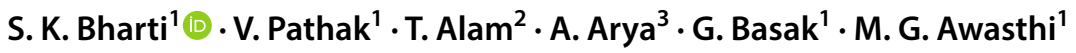

Received: 12 September 2019 / Accepted: 7 February 2020 / Published online: 20 February 2020

(c) The Author(s) 2020

\begin{abstract}
Muscle foods are extremely extensive food products that are relished throughout the world. They are known for their exclusive nutritional content and bio-availability however, at the same time, they also provide apposite media for the growth of pathogenic and spoilage microorganisms. Packaging seems to be a substantial approach to overcome this problem, but most of the packaging involves the usage of non-biodegradable and non-renewable material like plastic, nylon, polyester, etc. The alarming situation caused by synthetic material has been realized worldwide and several scientists, agencies, and the food industry are working globally to explore materials that are derived from the natural source. Biodegradable films are an excellent alternative to conventional plastics. These biodegradable films and coatings are derived from various biological sources and are receiving considerable importance in recent years. Different meat and meat product needs specific packaging condition and these active, composite bio-based films are having a wide potential in the meat sector. This review gathers the research and findings over the period of time-related to biodegradable edible film applied to muscle foods.
\end{abstract}

Keywords Edible film $\cdot$ Antimicrobial $\cdot$ Essential oil $\cdot$ Lipid-oxidation $\cdot$ Meat spoilage

\section{Introduction}

Globally meat-food sector plays an imperative role in countries' well-being as it not only caters the requirement of meat and edible by-products for human consumption, but also confers sustainable livestock development and subsistence security for millions of men and women from weaker sections. On account of supportive socio-economic factors such as changing eating habits, better purchasing power, urbanization, increasing apprehension towards protein-rich diet, there has been increasing in demand for meat and the sector has attained significant meaning in terms of contribution to income, employment and foreign exchange earnings [26].

S. K. Bharti

drskbharti@gmail.com

$1 \quad$ U.P. Pandit Deen Dayal Upadhyaya Pashu Chikitsa Vigyan Vishwavidyalaya Evam Go-Anusandhan Sansthan (DUVASU), Mathura 281001, India

2 Indian Institute of Packaging-Delhi, Plot No. 21 Fie Patparganj, Delhi 92, India

3 Department of Livestock Products Technology, College of Veterinary and Animal Science, GBPUAT, Pantnagar 263145, India
Since meat and meat products are having the richest nutritional matrix, its superiority is extremely prone to degradation due to digestive enzymes, microbial spoilage and lipid oxidation [140]. Distinctive technical operations are involved in the conversion of muscle to meat; inadequacy at any stage will result in a rigorous negative impact on the product and/ or process in the following stage. Besides hygiene and storage temperature, the acidity of the meat and the structure of the muscular tissue influence the degree of spoilage as well. Lipid oxidation, protein degradation and the debt of other important molecules are the results of meat spoilage progression. This deleterious break down of fat and protein is instigation for the production of contingent compounds eliciting changes in meat flavor, tenderness, juiciness, odor, texture and appearance. It is, therefore, necessary to prevent spoilage of meat and meat products to prolong the freshness of these muscle foods.

One customary way to overcome these problems along with the extension of the shelf life of such food is through packaging. Meat packaging once used principally as an inert barrier to protect its contents against contamination moreover this purpose has shifted towards harmonizing functions that complement product quality, permanence and customer/ retail presentation and be eco-friendliness. 
On this perspective use of bioactive food packaging to extend shelf life and safety of perishable food, particularly those susceptible to the microbial and chemical downturn, have gained noticeable interest. During the last three decades, considerable effort has been made by researchers/ industries studying packaging, materials, food processing, and biotechnology to design active food packaging materials together with creating awareness of going green. A newer concept dedicated to preserving the environment following the awareness of the amount of nonessential plastic waste produced from packaging goods is emerging. Moreover, the work done for antimicrobial and antioxidant effects of essential oil on such starch-based edible film for meat is scantly available. Therefore, realizing the need of alternative packaging techniques and enhancement for food safety using natural sources, this review is written to exhibit the well-being of biodegradable packaging beyond traditional packaging.

\section{Meat Sustenance and Vulnerability for Deterioration}

Nutrient richness makes meat, the first-choice source of animal protein to the consumer throughout the world [76]. Meat has conferred a crucial role in human evolution and is an influential section of a healthy and well-balanced diet. Muscle foods constitute a good nutrients source for diet, where their protein provides high biological value and essential amino acids which complement the quality of cereals and other vegetable proteins [182]. The important micronutrients are also best available from meat, e.g. Iron selenium and vitamin $A$ and $B_{12}$ and folic acid either because they do not exist in plant-derived food or because they are poorly available. Meat fat comprises mostly monounsaturated and saturated fatty acid with oleic, palmitoleic and stearic acid being the most ubiquitous. Such type of nutritionally condensed food is very much susceptible to chemical (oxidation) and microbiological (spoilage) deterioration and therefore represents a high risk for consumer health [76].

\section{Microbial Degradation}

Pre-slaughter handling of livestock and post-slaughter handling of meat play an important part in the deterioration of meat quality [41]. Microbes can be responsible for the spoilage of food when they breakdown the meat, acids and other meat waste products are created in the process. As the microbes itself may or may not be harmful, the waste products may be unpleasant to taste or may even be harmful to one's health. A common type of microbial spoilage of meat can be classified based on whether they occur under aerobic or anaerobic conditions and whether they are caused by bacteria, yeast or mold (Fig. 1).

In meat, pathogenic micrograms, specifically Campylobacter, Salmonella spp. (raw or undercooked meat particularly poultry), Staphylococcus aureus, Listeria monocytogenes (chilled, "ready-to-eat" foods, including pre-packed sandwiches, cooked sliced meats, and pâté), Clostridium perfringens, Clostridium botulinum, and Escherichia coli $\mathrm{O} 157: \mathrm{H} 7$ are of major concern as their presence not only deteriorate the quality but also gravitate to food safety issues [88].

Several studies already established that meat is most perishable of all foods $[139,144,173]$. The nutritional matrix and moist surface make it conducive to the colonization and growth of a wide range of spoilage bacteria. This has been described as loose and reversible sorption [48]. The next and irreversible stage of attachment involves the production of a sticky polysaccharide extracellular layer by the bacterium,
Fig. 1 Microbial spoilage in meat

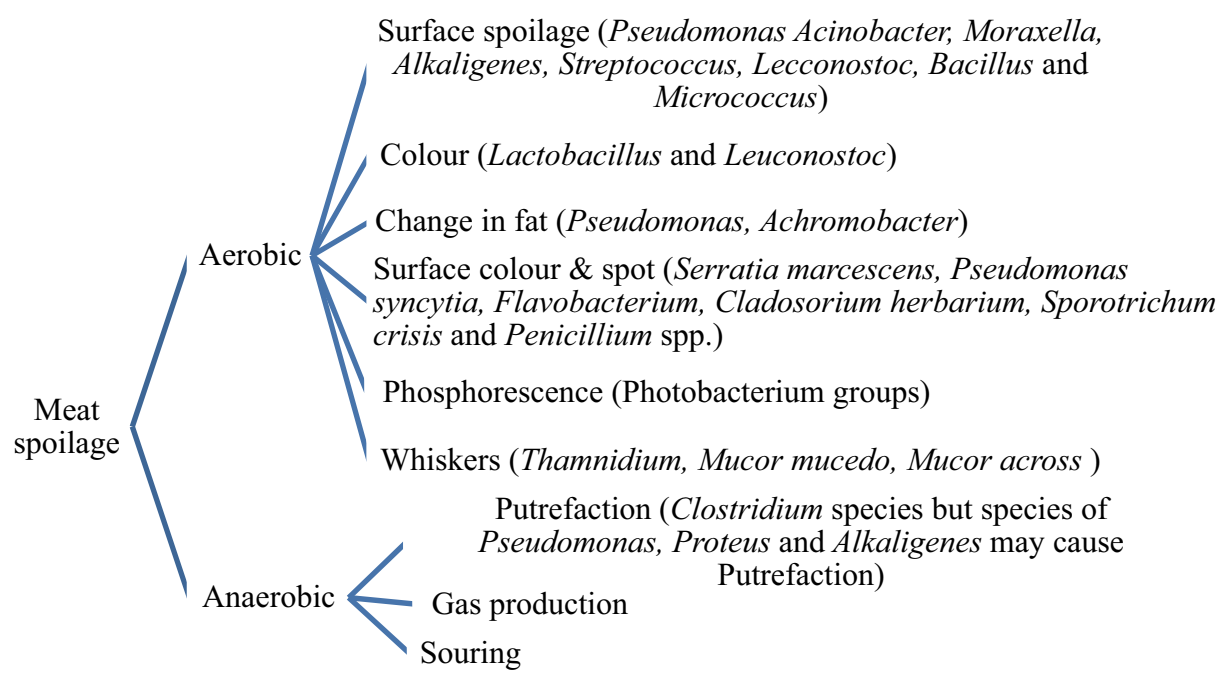


called the glycocalyx [40], that ultimately leads to the production of biofilm. This colonization is responsible for a change in the organoleptic property of meat that too varies according to species of colonizing bacteria, type of processing and storage condition of meat.

Meat borne diseases impede socioeconomic development by straining health care systems, harming national economies, tourism and trade. The situation becomes further susceptible with the implementation of GATT as food supply chains now cross multiple national borders.

\section{Lipid Peroxidation}

Modern consumer concerns over "Quality" and "healthfulness" by meat products have greatly changed during past decades. Sensory quality characteristics viz. appearance/ color, texture, and flavor are the main quality attributes that affect consumer acceptance of meat, and lipid peroxidation is the primary cause of these quality deteriorations in meat and meat products. Lipid oxidation is relatively a complex process whereby unsaturated fatty acids reacting with molecular oxygen via a free radical chain mechanism, form fatty acyl hydroperoxides, commonly called peroxides or primary products of the oxidation [110]. The primary autooxidation is followed by a series of secondary reactions that lead to the degradation of the lipid and the development of oxidative rancidity [46]. The problems associated with lipid oxidation have gained much interest as they relate to flavor deterioration, loss of nutritional value and safety, biological damage, aging, functional property changes, and environmental pollution. The off-flavors associated with oxidation are attributed to a number of different hydroperoxides which, in conjunction with the many different decomposition pathways involved, lead to a large number of volatile compounds [45]. Although the organoleptic aspects of lipid oxidation were considered, until recently, to be the most important to both producer and consumer, great attention has now been given to health risks that lipid oxidation might impose. Lipid hydroperoxides and their decomposition products may cause damage to proteins, membranes and biological components, thus affecting vital cell functions [117]. Products of lipid oxidation process are voted as chemical toxicants and are believed to lead to deteriorative processes in man, including aging [168]. Lipid peroxides and oxidized cholesterol may be involved in tumor promotion and atherosclerosis, whereas malonaldehyde, a secondary product of lipid oxidation, has been implicated as a catalyst in the formation of $\mathrm{N}$-nitrosamines and also as causing mutagenesis [110]. Refrigerated and frozen fresh meats are also susceptible to lipid oxidation and cooking makes them more vulnerable (Fig. 2). The process such as grinding, cooking and deboning (disrupting the muscle membrane system), results in exposure of the labile lipid components to oxygen and consequently accelerates the rancidity. As consumption of prepackaged raw meat and precooked is significantly increasing, control of oxidation has become ever more important. Realizing the problems associated with oxidation, a lot of work has been done to prevent rancidity in muscle foods and is still being carried out throughout the globe. The growing concerns of the consumer about the possible health risks from the use of additives in foods, the use of natural antioxidants have eventually gained importance.

\section{Containment of Muscle Food}

Packaging is an accessional characteristic that is gaining substance as a compulsory tool for meat quality maintenance. The purpose of any packaging system for muscle foods is to prevent or delay undesirable oxidative and microbiological deteriorative changes to the appearance, flavor, odor, texture and to extend the shelf life of the product [159]. Packaging

Fig. 2 Auto-oxidation of meat

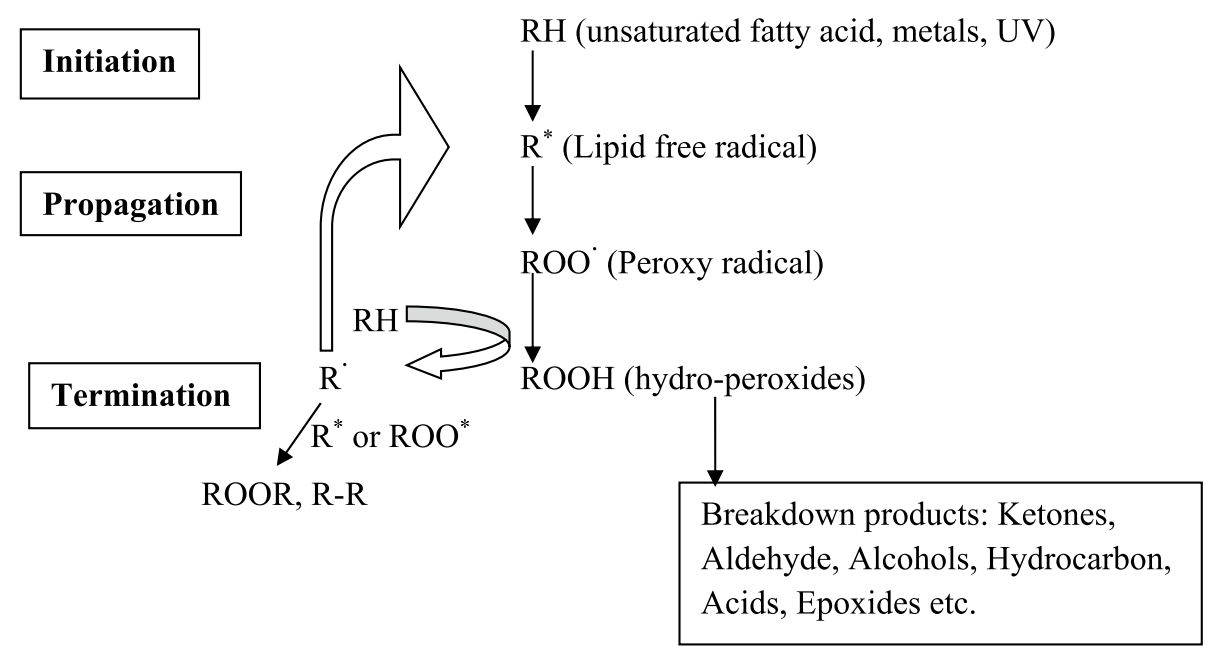


plays a more crucial role in meat and meat products as they deteriorate much faster and possess a higher potential for contamination as compared to other foods. Practically, the films used for meat packaging derive from synthetic "plastic" materials [76]. The most commonly used polymers for food packaging are low-density polyethylene, high-density polyethylene, polypropylene, and polyamide [85] polyesters, polyvinylidene chloride, polystyrene and ethylene/ vinyl acetate [121]. Contrasting packaging material has its advantages, disadvantages, consumer and marketing issues, and environmental considerations.

Polymers and plastics are typical materials of the last century and the continuous innovation around them helps to explain that since 1950, plastics production has increased by an average of almost $10 \%$ every year on a global basis [145]. The polymers and materials used for food-packaging today consist of a variety of petroleum-derived plastic materials [187], metals, glass, paper, and board, or combinations thereof, because of their availability in large quantities at low cost and favorable functionality characteristics. Except for paper and board, all major packaging materials are based on non-renewable materials [81], implying that at some point, more alternative packaging materials based on renewable resources have to be found to avoid problems concerning waste disposal [183]. Environmental devaluation and depreciation of fossil fuels provoked the use of renewable resources [60].

\section{Current Disposal Statistics of Plastic}

Global production of resins and fibers increased from $2 \mathrm{Mt}$ in 1950 to $380 \mathrm{Mt}$ in 2015, a compound annual growth rate of $8.4 \%$ [146]. The biggest groups in total non-fiber plastics fabrication are PE (36\%), PP (21\%), and PVC (12\%), followed by PET, PUR, and PS ( $<10 \%$ each). Polyester, most of which is PET, accounts for $70 \%$ of all PP\&A fiber production. Collectively, these seven groups account for $92 \%$ of the usual plastics manufactured [62].

However, most synthetic films are petrochemical-based and non-biodegradable; it takes several hundred years to degrade synthetic plastics [75] which has caused a very detrimental impact on the environment throughout the globe [136]. The growing consumer demand for healthier products that do not cause environmental pollution has led to a change in the approaches used for the manufacture of materials by the food packaging industry [159]. Natural polymers are now, progressively searched as packaging materials due to their eco-friendly nature.

Biodegradable films are the excellent alternative to conventional plastic or even biodegradable plastic in food industries. These biodegradable films and coatings can be prepared from various biological polymers such as polysaccharides, proteins or lipids and are receiving considerable importance in recent years. These films and coatings can protect a food product by serving as barriers to moisture migration, and preventing diffusion of gases important in food deterioration, such as $\mathrm{O}_{2}$ or $\mathrm{CO}_{2}[87,107]$. They can also enhance the quality and appearance of a food product by preventing flavor and aroma migration and by providing structural integrity.

\section{History of Edible Film and Coatings}

Edible films and protective coatings have been used for centuries to prevent quality loss such as shrinkage, oxidative off-flavors, microbial contamination, and discoloration in meat and poultry products [84]. Yuba, the first free-standing edible film, was developed in Japan from soymilk during the fifteenth century and was used for food preservation purposes [28]. In the sixteenth-century England, cut meats were coated in fats to reduce moisture loss and, thus, shrinkage in a process called "larding" [99]. Since then, a number of lipid coating formulations have been used to enhance the quality of meat and meat products. Letney [115] proposed coating meat with melted fat and letting it solidify to form a film to extend the storage life of meat products during refrigerated storage and maintain "bloom". Carnauba wax, beeswax, and candelilla have been used to coat frozen meat to increase its shelf life [44]. Use of acylated acylglycerol containing chlortetracycline [13], mixtures of mono-, di- and triacylglycerols in alcohol $[6,7]$ and acetylated mono- and diacylglycerol coatings have been suggested to reduce off-flavors and moisture loss, as well to maintain color and prevent freezer-burn in meat products. Applications of paraffinic acid mono-, diand triacylglycerol with or without carboxylic acid have also been reported to improve meat quality and storage life [160]. Griffin et al. [69] reported the application of acetylated mono acyl glycerol in vacuum-packed meats. Emulsion coatings containing lipids have also been demonstrated to be useful in enhancing meat quality [18]. Collagen films and sausage casings are probably the most successful commercial application of edible films in meat products [125].

\section{Edible Coating and Film}

Edible film is defined as thin, continuous or unbroken sheets made up of edible substances [16, 70]. Natural polymers like lipids and protein are used to produce environmental friendly edible films [123]. Edible packaging film and coatings are not generally meant to entirely replace conventional packaging, rather the efficiency of food preservation can be further improved by using primary edible packaging together with non-edible packaging as secondary packaging 
to add additional protection from the atmosphere and prevent contamination from microorganisms or foreign contaminants [112]. These films can be placed in between food elements, act as a food wrapper and a pocket to hold food [77]. Edible packaging generally consists of edible films, sheets, coatings, and pouches. Edible films (thickness $<254 \mu \mathrm{m}$ or $10 \mathrm{mil}$ ) or sheets (thickness $>254 \mu \mathrm{m}$ ) are stand-alone structures that are preformed separately from the food and then placed on or between food components or sealed into edible pouches [108], whereas edible coatings are thin layers of edible materials formed directly onto the surface of the food products.

The main advantage of edible films over traditional synthetics is that they can be consumed with the packaged products [87]. There is no package to dispose of even if the films are not consumed they could still contribute to the reduction of environmental pollution. The films are produced exclusively from renewable, edible ingredients and therefore are anticipated to degrade more readily than polymeric materials [30]. The main role of edible coatings is to preserve the high quality of a food product $[118,180]$. Edible films can extend the shelf life of processed food by providing barrier to moisture, gas, and lipid, as well as protection [86]. The films can enhance the organoleptic properties of packaged foods provided they contain various components (flavorings, colorings, sweeteners) [30].

Fresh meat requires oxygen for maintaining color and cured meats degrade in the presence of oxygen. These two parameters are significant while selecting packaging material i.e. shape or form and material. The film-forming solution is pretty cable of being molded to get a film of said characteristics. In addition, since the water activity $\left(a_{\mathrm{w}}\right)$ is critical for microbial, chemical, and enzymatic activities, Cha and Chinnan [36] demonstrated that films can resist the migration of moisture into the meat or poultry during the storage. Edible films and coatings can also serve as carriers for antimicrobials, antioxidants, nutrients, color, herbs, and spices, and provide for localized or delayed activity if needed.

The utilization of edible packaging can reduce the complexity of overall packaging requirements by allowing conversion from multilayer or multilevel packaging to a single-component package, resulting in source reduction and improved recyclability [102] of the simplified packaging system without compromising protective functions [107]. Edible Films and Coatings in accordance with good manufacturing practices must typically have the approval of the Food and Drug Administration (FDA) as Generally Recommended as Safe (GRAS) items [8] (Fig. 3).

\section{Biopolymers}

Components of edible films can be divided into three categories: hydrocolloids, lipids, and composites. Hydrocolloids include proteins and polysaccharides, such as starch, alginate, cellulose derivatives, chitosan, and agar. Lipids include waxes, acylglycerols, and fatty acids [126]. Composites contain both hydrocolloid components and lipids [5]. The choice of formulation for biopolymers is largely dependent on its desired function such as aesthetic appearance and good barrier properties against oxygen [36].

Structuring biopolymers, polysaccharides such as chitosan [53], hemicelluloses [74] and starch [89], proteins [151], and lipids [49] have been used for the formulation of edible films for meat. Gelatin is a denatured protein derived from collagen by thermal hydrolysis [111] possesses excellent film-forming and barrier properties against oxygen and light [2]. Sodium caseinate, a mixture of casein monomers and small aggregates [166] formed after the removal of colloidal calcium phosphate from casein micelles has been found suitable by Pankaj et al. [135] for packaging of meat.

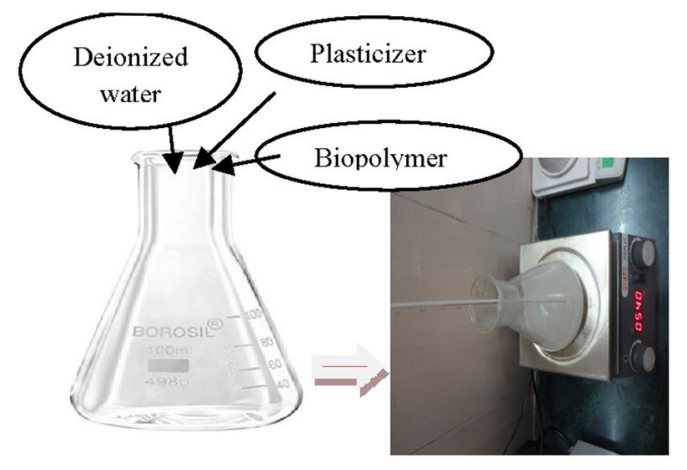

Film-forming dispersion
Homogenization

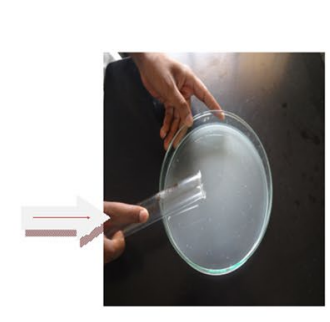

Casting

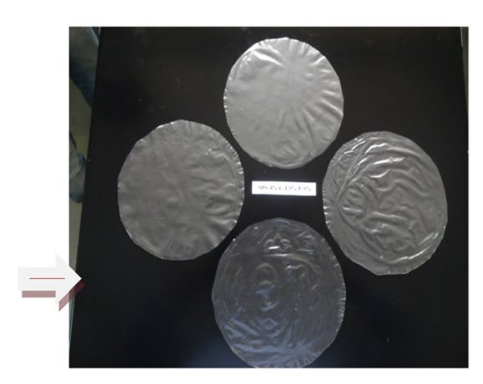

Edible film

Fig. 3 Preparation of edible film (Source: [25]) 


\section{Polysaccharide-based Films}

Polysaccharides are most often used for edible films because their film-forming properties are derived from starch, alginate, dextrins, pectin, chitosan, carrageenans and their mixtures [73]. These are non-toxic, widely available, selectively permeability to $\mathrm{CO}_{2}$ and $\mathrm{O}_{2}$ and are hydrophilic in nature. For this reason, these films are poor barrier to water vapor [131] and allow movement of water vapor across the film, thus, preventing water condensation that can be a potential source of microbial spoilage [36].

\section{Starch}

Edible or biodegradable starch films primarily derived from cereal grains, potatoes, tapioca, or arrowroot starch or its components, amylose and amylopectin, by two main techniques: solution casting and subsequent drying (wet method) and thermoplastic processing (dry method) [134]. Amylose is a nearly linear polymer of $\alpha-1,4$ anhydroglucose units [33, 116]. Amylose content of starch is responsible for its filmforming capacity [39]. Starch containing high amylose produces films with higher flexibility, oxygen impermeability, oil resistance; heat-seal ability, and water solubility. Films of high-amylose corn starch or potato starch was more stable during aging [109]. Starch-based films display similar physical characteristics to plastic films as that they are also odorless, tasteless, colorless, transparent [89], non-toxic, biologically absorbable, semi-permeable to carbon dioxide, and resistant to the passage of oxygen. Mohan et al. [127] used S. aromaticum and C. cassia fused starch edible films to enhance shelf life of mutton (Capra aegagrus hircus) meat. Tosati et al. [177] found a significant antimicrobial effect of edible coating based on turmeric starch residue and gelatin onto fresh frankfurter sausage. Bhattacharya and Kandeepan [27] did the selection of biopolymers to develop a biodegradable and edible film for packaging of luncheon chicken meat slices. Alotaibi and Tahergorabi [4] developed sweet potato starch-based coating to enhance the quality attributes of shrimp during refrigerated storage. Development of potato starch based active packaging films loaded with antioxidants and its effect on shelf life of beef was done by Nisa et al. [130].

\section{Carrageenan}

Carrageenan is a collective term used to express 'polysaccharides' that are extracted from certain species of red seaweed of the Rhodophycae family. Carrageenans are anionic linear sulfated polysaccharides composed of D-galactopyranose residues bonded by regularly alternating a-(1/3) and $\mathrm{b}-(1 / 4)$ bonds. $\mathrm{k}$-car is the most commercially used carrageenan out of the three main types of carrageenans, the others being i-carrageenan and l-carrageenan. k-car contains one negatively charged sulfate group and has 3,6-anhydroD-galactopyranose residues in the chain that impart k-car the ability to form gels [174].

Polysaccharide-based coatings including carrageenan have good gas barrier properties [137]. Carrageenan, as edible films and coatings have already covered various fields of the food industry such as an application on fresh and frozen meat, poultry and fish to prevent superficial dehydration [165], sausage-casings [143]. Bharti [25] developed and characterized essential oils incorporated starch and carrageenan based edible film for packaging of chicken nuggets.

\section{Chitosan}

Chitosan is the second most abundant natural and non-toxic polymer in nature after cellulose and is mainly made from crustacean shells. In industrial processing, chitin is extracted by acid treatment to dissolve the calcium carbonate followed by an alkaline solution to dissolve proteins. In addition, a decolorization step is often added to remove pigments and obtain colorless pure chitin [188]. Chitosan films are advantageous as it forms films without the addition of additives, exhibits good oxygen and carbon dioxide permeability along with excellent mechanical and barrier properties [55]. Chitosan also exhibits strong antimicrobial activity against bacteria, yeasts and molds [71].

Chitosan films prepared with oregano essential oil were applied to bologna slices and suggested as an antimicrobial packaging material for processed meat [37]. Karimnezhad et al. [97] showed enhanced antimicrobial effects of chitosan-based edible film containing Trachyspermum ammi essential oil on shelf-life of chicken meat and Thymus vulgaris L. essential oil [148] in ready-to-eat meat. The sensory, physicochemical and microbiological quality of pastirma (a traditional dry-cured meat product) was improved by using chitosan coating [1]. Chitosan-based nanofibers films show in situ bioactivity against $E$. coli as a bioactive barrier to meat contamination [9] developed as bioactive meat packaging materials.

\section{Alginates}

Alginates are derived from brown seaweed (commercially from Macrocystis pyrifera, Laminaria hyperborea, Laminaria digitata, and Ascophyllum nodosum) and, in the presence of divalent cations, producing films that are particularly useful for applications that enhance the quality of meat and poultry products [131]. Calcium is the most common and effective divalent cation in gelling alginates, though magnesium, manganese, aluminum, ferrous, or ferric ions are also used [99]. Alginate film strength may further be improved in the presence of modified starches, oligosaccharides or 
simple sugars [61]. Raeisi et al. [149] found the improved microbial quality of chicken meat with sodium alginate coating incorporated with nisin, Cinnamomum zeylanicum, and rosemary essential oils on the fate of Listeria monocytogenes during refrigeration. Vital et al. [179] found the superiority of alginate-based edible coating containing natural antioxidants (rosemary and oregano essential oils) on lipid oxidation, color perseverance, water losses, textural profile and $\mathrm{pH}$ of beef steaks.

\section{Protein-based Films}

Film-forming proteins are derived from animals (casein, whey protein concentrate and isolate, collagen, gelatin, and egg albumin) or plant sources (corn, soybean, wheat, cottonseed, peanut, and rice). Protein-based films adhere well to the meat hydrophilic surfaces and provide a barrier for oxygen and carbon dioxide but do not resist water diffusion [42]. Films prepared from proteins and carbohydrates are excellent barriers to oxygen, because of their tightly packed matrix and ordered hydrogen-bonded network structure [187].

Plasticizers, such as polyethylene glycol or glycerol, are added to improve flexibility of the protein network, whereas water permeability can be overcome by adding hydrophobic materials such as beeswax or oils like oleic that can affect films properties such as crystallinity, hydrophobicity, surface charge, and molecular size, improving films characteristics and their application [80]. Despite so many advantages, protein films may be susceptible to proteolytic enzymes present in meat products or allergenic protein fractions, which may cause adverse reactions to the sensitive populace [61].

Yang et al. [186] found improved antioxidant activities of distiller dried grains with solubles as protein films containing tea extracts in the packaging of pork meat. Akcan et al. [3] found antioxidant protection of cooked meatballs during frozen storage by whey protein edible films containing phytochemicals from Laurus nobilis L. and Salvia officinalis. Gallego et al. [59] developed gelatine-based antioxidant packaging containing Caesalpinia decapetala and Tara as a coating for ground beef patties. Catarino et al. [35] found the improved performance of whey protein active coatings with Origanum virens essential oils in the quality and shelf-life improvement of processed meat products. Antioxidant active packaging with soy edible films and oregano or thyme essential oils for oxidative stability of ground beef patties [104].

\section{Lipid-based Films}

A wide range of hydrophobic compounds has been used to produce EFC, including animal and vegetable oils and fats (peanut, coconut, palm, cocoa, lard, butter, fatty acids, and mono-, di- and triglycerides), waxes (candelilla, carnauba, beeswax, jojoba, and paraffin), natural resins (chicle, guarana, and olibanum), essential oils and extracts (camphor, mint, and citrus fruits essential oils), and emulsifiers and surface-active agents (lecithin, fatty alcohols, and fatty acids) [49].

Films composed of lipids have good water vapor barrier properties but exhibit reduced mechanical strength and increased oxygen permeability. When such ingredients are combined, they could physically and/or chemically interact and may result in films with improved properties [50]. To conquer the poor mechanical strength of these films, they can be used in combination with hydrophilic materials using the formation of an emulsion or through lamination with a hydrocolloid film lipid layer [29]. Karbowiak et al. [95] validated that the efficiency of an edible film against moisture transfer cannot be simply enhanced by the addition of hydrophobic materials in the formulation unless the formation of a homogeneous and continuous lipid layer inside the hydrocolloid matrix is achieved. Fabra et al. [56] and Jimenez et al. [90] found that fatty acids can form stable layers in film matrices, whose properties depend on their chain length i.e. the lower the chain length, the greater the layers.

In meat products, emulsifiers and surface-active agents are sometimes used as gas and moisture barriers. However, pure lipids can be combined with hydrocolloids such as protein, starch, cellulose, and their derivatives providing a multi-component system able to be applied as meat coatings [42]. Gennadios et al. [61] found that lipid incorporation into edible film coating can improve hydrophobicity, cohesiveness, and flexibility, making excellent moisture barriers, leading to prolongation of freshness, color, aroma, tenderness, and microbiological stability in fresh and processed meats.

\section{Composite Edible Films}

Multi-component or composite EF has been optimized attending to its mechanical properties and transparency, looking for consumer's acceptability and for the ability to withstand mechanical stress and handling during the transport [133]. Sabina and Andrzej [155] found superior composite films prepared by casting sodium alginate and low methoxy pectin. However, when lipids are added for improving moisture barrier properties, other features such as transparency can be affected [90].

\section{Nanocomposite Film}

The use of bio-nano composite materials for edible packaging promises to improve barrier and mechanical properties beyond what could be achieved by utilizing macroscopic reinforcing components [15]. Nanocomposite coatings demonstrate materials of a new generation that composed of at least two phases 
along with a nanocrystalline and/or amorphous component [175]. Simply, nanocomposite coating is a matrix composed of at least two immiscible phases, separated from one another by interface region. Accordingly, the material must contain the nanometer scale in at least one dimension in which the major component is dispersed [129]. The uniform dispersion of nanoparticles causes the formation of a very large matrix/filler interfacial area, which changes the nanostructure, molecular mobility, relaxation behavior, and the consequent thermal and mechanical properties of the final film [43]. Furthermore, the nanocomponents are expected to improve barrier properties by increasing the tortuosity of the path that water, gases, or lowmolecular-weight compounds take to penetrate the films [47].

Sani et al. [157] developed a nanocomposite film of Whey protein isolate/cellulose nanofibre/ $\mathrm{TiO}_{2}$ nanoparticle/rosemary essential oil and found enhanced microbial and sensory quality of lamb meat during refrigeration storage. Zhang et al. [190] characterized microemulsion nanofilms based on Tilapia fish skin gelatine and $\mathrm{ZnO}$ nanoparticles incorporated with ginger essential oil and found reduced antioxidative property towards lipid oxidation during storage.

\section{Roles of Plasticizer}

Plasticizers are low molecular weight non-volatile [161], high boiling point liquids with average molecular weights of between 300 and 600 , and linear or cyclic carbon chains (14-40 carbons) [51, 184] additives used to increase the flexibility or plasticity of polymers, and occasionally used only to facilitate the polymer processing. The most commonly used plasticizers in starch-based films are polyols, such as sorbitol and glycerol [38]. They are frequently added into edible films to reduce the intermolecular forces and increase the mobility of the polymeric chains, intersperse and intercalate among and between polymer chains, disrupting hydrogen bonding and spreading the chains apart, which not only increases flexibility [52], but also water vapor and gas permeabilities [17, 171]. Glycerol is often used to modify the mechanical properties [124] of hydrophilic films. With increasing concentration of glycerol into films, there is a reduction in internal hydrogen bonding between polymer chains while an increase in molecular volume, resulting in improved film flexibility [120].

\section{Use of Antimicrobials and Antioxidant in Edible Film}

Quite recently, the idea of incorporating antimicrobial agents directly into packaging films has been developed. Thus, the packaging material can serve as a source of releasing preservatives or antimicrobial agents or even prevent the growth of microorganisms. Several antimicrobial compounds viz. organic acids (acetic, propionic, benzoic, sorbic, lactic, lauric), potassium sorbate, bacteriocins (nisin, lacticin), grape seed extracts, spice extracts (thymol, $p$-cymene, cinnamaldehyde), thiosulfinates (allicin), enzymes (peroxidase, lysozyme), proteins (conalbumin), isothiocyanates (allylisothicyanate), antibiotics (imazalil), fungicides (benomyl), chelating agents (EDTA), metals (silver), or parabens (heptylparaben) can be added to edible films to reduce bacteria in solution, on culture media, or a variety of muscle foods. The incorporated antimicrobial agents must be edible food-grade compounds since they have to be consumed along with the edible gels, films, or coatings $[41,72]$.

The addition of antioxidants is a traditional method of controlling oxidative deterioration in meats and meat products [11]. One promising approach for optimizing effective usage of these antioxidants is active packaging with the incorporation of active substances into food packaging materials [128]. Research in this area has been directed toward utilization of biodegradable packaging materials because of the negative environmental impact of plastics; thus, attention has been paid to edible films (EF) and coatings that can serve as good carriers for many food additives, including antioxidants [147]. There is limited research on antioxidant active packaging for food applications using EFs and coatings [104, 132].

\section{Essential Oil}

Essential oils derived from natural sources have been added to the film as an antimicrobial agent [141]. Essential oils categorized as GRAS (generally recognized as safe) by US Food and Drug Administration [142]. Several new studies have been conducted to observe the effects of EOs obtained from sources such as rosemary, oregano, thyme, sage, basil, ginger, turmeric, coriander, garlic, nutmeg, clove, mace, savory, and fennel, when used alone or in combination with other EOs and/or preservation methods, to improve the sensory qualities and extend the shelf life of meat and meat products $[10,67]$.

The ability of plant essential oils to protect foods against pathogenic and spoilage microorganisms has been reported by several researchers $[31,58,152]$. To achieve an effective antimicrobial activity in direct food applications, high concentrations of essential oils are generally needed, which might impact inappropriate flavors and odors in the product [163]. Various spices and essential oils have preservative properties and have been used to extend the storage life of meat products for instance eugenol in cloves and allyl isothiocyanate in mustard seed [156]. 
Table 1 Essential oil incorporated edible film for antimicrobial property

\begin{tabular}{|c|c|c|c|}
\hline Film & Essential oil & Substrate & References \\
\hline Skate skin gelatin films & Thyme essential oil & Chicken tenderloin & Lee et al. [113] \\
\hline Sodium alginate coating & $\begin{array}{l}\text { Cinnamomum zeylanicum, and rosemary } \\
\text { essential oils }\end{array}$ & Chicken meat & Raeisi et al. [149] \\
\hline Sodium alginate & Rosemary and oregano essential oils & Beef & Vital et al. [179] \\
\hline Plantago major seed mucilage & Anethum graveolens essential oil & Beef & Behbahani et al. [22] \\
\hline Carrageenan & Oregano and thyme essential oils & Chicken patties & Soni et al. [170] \\
\hline Chitosan-based & Clove oil & Cooked pork sausages & Lekjing [114] \\
\hline Chitosan films & Thymus vulgaris L. essential oil & Ready-to-eat meat & Quesada et al. [148] \\
\hline Whey protein edible films & $\begin{array}{l}\text { Phytochemicals from Laurus nobilis L. } \\
\text { and Salvia officinalis }\end{array}$ & Cooked meatballs & Akcan et al. [3] \\
\hline Chitosan & Cumin and eucalyptus essential oils & Fresh chicken meat & Sharafati Chaleshtori et al. [164] \\
\hline$\kappa$-carrageenan & Procyanidin & Pork loin meat & Kim et al. [103] \\
\hline Cassava starch films & Oregano essential oil & Ground beef & Caetano et al. [32] \\
\hline Polylactic acid films & Lemongrass oil & Pork sausages & Yang et al. [186] \\
\hline $\begin{array}{l}\text { Active starch biopolymeric packaging } \\
\text { film }\end{array}$ & Essential oil of Syzygium aromaticum & Sausages & Ugalde et al. [178] \\
\hline Chitosan coating & Cinnamomum zeylanicum oil & Chicken meat nuggets & Khare et al. [100] \\
\hline Carrageenan & Cinnamon oil & Chicken fillets & Khare et al. [101] \\
\hline Chitosan film & $\begin{array}{l}\text { Anise (Pimpinella anisum L.) essential } \\
\text { oil }\end{array}$ & Chicken burger & Mahdavi et al. [119] \\
\hline $\begin{array}{l}\text { Microemulsion nanofilms based on } \\
\text { Tilapia fish skin gelatine: }\end{array}$ & Ginger essential oil & Meat & Zhang et al. [190] \\
\hline Sodium alginate coatings & Green tea & Chicken nuggets & Kristam et al. [106] \\
\hline Sweet potato starch coating & Thyme oil & Shrimp & Alotaibi and Tahergorabi [4] \\
\hline Soy edible films & Oregano or thyme essential oils & Ground beef & Kodal Coşkun et al. [104] \\
\hline Chitosan edible films & $\begin{array}{l}\text { Thymus moroderi and Thymus piperella } \\
\text { essential oil }\end{array}$ & Cooked cured ham & Ruiz-Navajas et al. [154] \\
\hline Chitosan coatings & Garlic oil & Shrimp & Aşik and Candoğan [12] \\
\hline Chitosan films & Cinnamon and ginger & Pork & Wang et al. [181] \\
\hline Whey protein active coatings & Origanum virens essential oils & Processed meat products & Catarino et al. [35] \\
\hline Sodium alginate edible films & Oregano essential oil & Ham slices & Pavli et al. [138] \\
\hline $\begin{array}{l}\text { Chitosan-montmorillonite bionanocom- } \\
\text { posites }\end{array}$ & Rosemary essential oil & Fresh poultry meat & Souza et al. [172] \\
\hline Chitosan-based edible film & Oregano essential oil & Fresh chicken meat & Karimnezhad et al. [96] \\
\hline $\begin{array}{l}\text { Sodium alginate and carboxymethyl cel- } \\
\text { lulose edible coating }\end{array}$ & Ziziphora essential oil & Fresh pork & Ruan et al. [153] \\
\hline
\end{tabular}

\section{Antimicrobials}

Meat and meat products being primary causes of foodborne diseases are also prone to spoilage during storage as with all proteinous foods [34]. EOs have been shown to possess antibacterial and antifungal against several microorganisms associated with meat, including Gram-negative and Grampositive bacteria [94].

Regarding the meat and meat products, EOs from oregano [162], rosemary, thyme [189], clove [167], balm, ginger, basilica, coriander, marjoram, and basil have shown a greater potential to be used as an antimicrobial agent [19, 57, 68, 169]. Essential oils rich in phenolic compounds like clove, oregano, rosemary, thyme, sage and vanillin oils be the most effective [78]. Cutter [42] demonstrated that antimicrobial agents, when incorporated into the packaging films, could be effective for reducing levels of foodborne organisms.

Oregano essential oil has been the most commonly reported, including a $1.5 \%$ extract $(\mathrm{v} / \mathrm{v})$, successfully used to reduce total viable count by $2 \log \mathrm{CFU} / \mathrm{g}$ of cold-smoked sardine [98], whereas at $1.9 \%$ it achieved L. monocytogenes population reduction by $2.4 \log \mathrm{CFU} / \mathrm{g}$ after 28 days, at $4{ }^{\circ} \mathrm{C}$ in wrapped cold-smoked salmon [105]. Combined Oregano essential oil and thyme extract, was incorporated into a film placed on top and bottom of fresh ground beef patties reducing Pseudomonas and coliforms count [21], whereas mixed with pimento essential oil, the films covering beef muscle slices reduced to $1 \log$ of E. coli $\mathrm{O} 157: \mathrm{H} 7$ 
Table 2 Essential oil incorporated edible film for antioxidative property

\begin{tabular}{|c|c|c|c|}
\hline Film & Essential oil & Substrate & References \\
\hline Milk protein-based edible films & $\begin{array}{l}1.0 \%(\mathrm{w} / \mathrm{v}) \text { oregano, } 1.0 \%(\mathrm{w} / \mathrm{v}) \text { pimento, } \\
\text { or } 1.0 \% \text { oregano-pimento }(1: 1) \text { essential } \\
\text { oils }\end{array}$ & Whole beef muscle & Oussalah et al. [132] \\
\hline Gelatin-based functional edible films & $\begin{array}{l}\text { Oregano (Origanum vulgare) or Rose- } \\
\text { mary (Rosmarinus officinalis) }\end{array}$ & $\begin{array}{l}\text { Cold-smoked sardine } \\
\text { (Sardina pilchar- } \\
\text { dus })\end{array}$ & Gómez-Estaca et al. [65] \\
\hline Chitosan film & $\begin{array}{l}\text { Clove (Syzygium aromaticum L.), fennel } \\
\text { (Foeniculum vulgare Miller), cypress } \\
\text { (Cupressus sempervirens L.), laven- } \\
\text { der (Lavandula angustifolia), thyme } \\
\text { (Thymus vulgaris L.), herb-of-the-cross } \\
\text { (Verbena officinalis L.), pine (Pinus } \\
\text { sylvestris) and rosemary (Rosmarinus } \\
\text { officinalis) }\end{array}$ & Fish & Gómez-Estaca et al. [64] \\
\hline Plantago major seed mucilage & Anethum graveolens essential oil & Beef & Behbahani et al. [22] \\
\hline Gelatin composite films & Nanorods/clove essential oil & Shrimp packaging & Ejaz et al. [54] \\
\hline Whey protein active coatings & Origanum virens essential oils & Processed meat & Catarino et al. [35] \\
\hline Chitosan film & $\begin{array}{l}\text { Anise (Pimpinella anisum L.) essential } \\
\text { oil }\end{array}$ & Chicken burger & Mahdavi et al. [119] \\
\hline Chitosan edible films & $\begin{array}{l}\text { Thymus moroderi and Thymus piperella } \\
\text { essential oil }\end{array}$ & Cooked cured ham & Ruiz-Navajas et al. [154] \\
\hline Alginate-based edible coating & Rosemary and oregano essential oils & Beef & Vital et al. [179] \\
\hline Quince seed mucilage edible films & Oregano or thyme essential oil & Rainbow trout fillets & Jouki et al. [92] \\
\hline $\begin{array}{l}\text { Silver carp (Hypophthalmichthys molitrix) } \\
\text { skin gelatin-chitosan }\end{array}$ & Oregano essential oil & Fish & Wu et al. [185] \\
\hline $\begin{array}{l}\text { Pomegranate juice dipping and chitosan } \\
\text { coating }\end{array}$ & Zataria multiflora Boiss essential oil & Chicken meat & Bazargani-Gilani et al. [20] \\
\hline Carboxymethyl cellulose edible coating & Zataria multiflora essential oil & Rainbow trout meat & Raeisi et al. [150] \\
\hline Soy edible films & Oregano or thyme essential oils & Ground beef patties & Kodal Coşkun et al. [104] \\
\hline Chitosan-gelatin film & Ziziphora clinopodioid essential oil & Minced trout fillet & Kakaei and Shahbazi [93] \\
\hline Chitosan nanoparticles & Cinnamon essential oil & Chilled pork & Hu et al. [83] \\
\hline Chitosan coatings & Zataria multiflora Boiss oil & Chicken breast meat & Mehdizadeh and Langroodi [122] \\
\hline Pectin-fish gelatin films & Olive & Beef meat & Bermúdez-Oria et al. [24] \\
\hline Chicken meat protein coatings & Thyme or clove essential oil & Beef sucuks & Saricaoglu and Turhan [158] \\
\hline
\end{tabular}

after 7 days of storage at $4{ }^{\circ} \mathrm{C}$ [66]. Grapefruit seed extract (GSE) incorporated into AEFC was found to inhibit $E$. coli O157:H7 and L. monocytogenes from pork loins [147], bacon [167] (Table 1).

\section{Antioxidant}

Oxygen is responsible for many degradation processes in foods such as lipid oxidation, micro-organism growth, enzymatic browning and vitamin loss [14]. The oxidation of fat results in off-flavor, off-color and nutrient loss [79]. Essential oils from oregano [189], sage rosemary, thyme, and pimiento are reported to possess antioxidant properties comparable to or greater than BHA or butylated hydroxytoluene (BHT) [23, 82]. Oussalah et al. [132] reported the antioxidant properties of milk protein-based edible films containing oregano, pimiento and oregano-pimiento mix. Pimiento-containing films provided the highest antioxidant activity on beef muscle slices; oregano-based films were also able to inhibit lipid oxidation in beef muscle samples.

Fortifying films with bioactive ingredients such as citrusbased essential oils [176], green tea extract [63], butylatedhydroxy-toluene (BHT) and a-tocopherol [91]. Seaweed extracts, being rich in phycocolloids, phenolics, and other antioxidative compounds, are a very good source for the fortification of biopolymer-based films (Table 2). 


\section{Conclusion}

The use of edible films and coatings represents a stimulating route for creating new food packaging materials. Contrasting edible films have been developed by researchers for meat packaging over the years. However, some challenges like economy, applicability and least sensorial alteration of meat and meat products still remains. All of these shortcomings lead to flawed liaisoning between the researchers and industry emanating limited commercial acceptance. The frequent benefits of technique to food processors and consumers by effective edible film packaging must be justified and further research in this field is realized.

Open Access This article is licensed under a Creative Commons Attribution 4.0 International License, which permits use, sharing, adaptation, distribution and reproduction in any medium or format, as long as you give appropriate credit to the original author(s) and the source, provide a link to the Creative Commons licence, and indicate if changes were made. The images or other third party material in this article are included in the article's Creative Commons licence, unless indicated otherwise in a credit line to the material. If material is not included in the article's Creative Commons licence and your intended use is not permitted by statutory regulation or exceeds the permitted use, you will need to obtain permission directly from the copyright holder. To view a copy of this licence, visit http://creativecommons.org/licenses/by/4.0/.

\section{References}

1. Abdallah MR, Mohmaed MA, Mohamed HM, Emara MM (2017) Improving the sensory, physicochemical and microbiological quality of pastirma (a traditional dry cured meat product) using chitosan coating. LWT Food Sci Technol 86:247-253

2. Ahmad M, Benjakul S, Prodpran T, Agustini TW (2012) Physico-mechanical and antimicrobial properties of gelatin film from the skin of unicorn leatherjacket incorporated with essential oils. Food Hydrocoll 8:189-199

3. Akcan T, Estévez M, Serdaroğlu M (2017) Antioxidant protection of cooked meatballs during frozen storage by whey protein edible films with phytochemicals from Laurus nobilis L. and Salvia officinalis. LWT Food Sci Technol 77:323-331

4. Alotaibi S, Tahergorabi R (2018) Development of a sweet potato starch-based coating and its effect on quality attributes of shrimp during refrigerated storage. LWT Food Sci Technol 88:203-209

5. da Altenhofen SM, Krause BAC, Guenter KT (2009) Alginate and pectin composite films cross linked with $\mathrm{Ca}^{2+}$ ions: effect of the plasticizer concentration. Carbohyd Polym 77:736-742

6. Anderson TR (1961a) U.S. patent 2989401

7. Anderson TR (1961b) U.S. patent 2989402

8. Arantzazu V, Ana CM, Marina R, Maria CG, Alfonso J (2014) Natural additives and agricultural wastes in biopolymer formulations for food packaging. Front Chem. https://doi.org/10.3389/ fchem.2014.00006

9. Arkoun M, Daigle F, Holley RA, Heuzey MC, Ajji A (2018) Chitosan-based nanofibers as bioactive meat packaging materials. Packag Technol Sci. https://doi.org/10.1002/pts.2366

10. Arya A, Mendiratta SK, Agarwal RK, Bharti SK, Umarao P (2019) Antimicrobial profile and organoleptic acceptability of some essentials oils and their blends in hurdle treated chicken meat spread. Int J Curr Microbiol Appl Sci 8(9):2162-2177

11. Arya A, Mendiratta SK, Singh TP, Agarwal R, Bharti SK (2017) Development of sweet and sour chicken meat spread based on sensory attributes: process optimization using response surface methodology. J Food Sci Technol 54(13):4220-4228

12. Aşik E, Candoğan K (2014) Effects of chitosan coatings incorporated with garlic oil on quality characteristics of shrimp. J Food Qual 37(4):237-246

13. Ayers JC (1959) Use of coating materials or film impregnated with chlortetracy-cline to enhance color and shelf life of fresh beef. Food Technol 13:512-515

14. Ayranci E, Tunc S (2003) A method for the measurement of the oxygen permeability and the development of edible films to reduce the rate of oxidative reactions in fresh foods. Food Chem $80: 423-431$

15. Azeredo HMC, Mattoso LHC, Wood D, Williams TG, Avena BRJ, McHugh TH (2009) Nanocomposite edible films from mango puree reinforced with cellulose nanofibers. J Food Sci 74(5):31-35

16. Balasubramaniam VM, Chinnan MS, Mallikarjunan P, Philips RD (2007) The effect of edible film on oil uptake and moisture retention of deep-fat fried poultry product. J Food Process Eng 20(1):17-29

17. Baldwin EA, Baker RA (2002) Use of proteins in edible coatings for whole and minimally processed fruits and vegetables. In: Gennadios A (ed) Protein-based films and coatings. CRC Press, Boca Raton, pp 501-515

18. Baldwin EA, Nisperos CMO, Hagenmaier RD, Baker RA (1997) Use of lipids in coatings for food products. Food Technol 51(6):56-64

19. Barbosa LN, Rall VLM, Fernandes AAH, Ushimaru PI, Probst IS, Fernandes AJ (2009) Essential oils against foodborne pathogens and spoilage bacteria in minced meat. Foodborne Pathog Dis 6(6):725-728

20. Bazargani-Gilani B, Aliakbarlu J, Tajik H (2015) Effect of pomegranate juice dipping and chitosan coating enriched with Zataria multiflora Boiss essential oil on the shelf-life of chicken meat during refrigerated storage. Innov Food Sci Emerg Technol 29:280-287

21. Begin A, Van CMR (1999) Antimicrobial films produced from chitosan. Int J Biol Macromol 26:63-67

22. Behbahani BA, Shahidi F, Yazdi FT, Mortazavi SA, Mohebbi M (2017) Use of Plantago major seed mucilage as a novel edible coating incorporated with Anethum graveolens essential oil on shelf life extension of beef in refrigerated storage. Int J Biol Macromol 94:515-526

23. Bendini A, Gallina TG, Lercker G (2002) Antioxidant activity of oregano (Origanum vulgare L.) leaves. Ital J Food Sci $14: 17-24$

24. Bermúdez-Oria A, Rodríguez-Gutiérrez G, Rubio-Senent F, Fernández-Prior Á, Fernández-Bolaños J (2019) Effect of edible pectin-fish gelatin films containing the olive antioxidants hydroxytyrosol and 3, 4-dihydroxyphenylglycol on beef meat during refrigerated storage. Meat Sci 148:213-218

25. Bharti SK (2019) Development of starch based edible film incorporated with essential oil for enhancing shelf life of chicken nuggets. PhD Thesis DUVASU, Mathura

26. Bharti SK, Pathak V, Goswami M, Sharma S, Ojha S, Anita (2017) Quality assessment of Nelumbo nucifera supplemented functional muscle food. J Entomol Zool Stud 5(4):445-451

27. Bhattacharya D, Kandeepan G (2017) Selection of biopolymers to develop a biodegradable and edible film for packaging of luncheon chicken meat slices. Asian J Dairy Food Res 36(1):67-71 
28. Biquct B, Guilbert S (1986) Relative diffusivities of water in model intermediate moisture foods. LWT Food Sci Technol 19:208-214

29. Bourlieu C, Guillard V, Vallès-Pamies B, Gontard N (2008) Edible moisture barriers for food product stabilization. In: Aguilera JM, Lillford PJ (eds) Food materials science. Springer, New York, pp 547-575

30. Bourtoom T (2008) Edible films and coatings: characteristics and properties. Int Food Res J 15(3):237-248

31. Burt S (2004) Essential oils: their antibacterial properties and potential applications in food-a review. Int J Food Microbiol 94:223-253

32. Caetano KDS, Hessel CT, Tondo EC, Flôres SH, Cladera-Olivera F (2017) Application of active cassava starch films incorporated with oregano essential oil and pumpkin residue extract on ground beef. J Food Saf 37(4):e12355

33. Campos CA, Gerschenson LN, Flores SK (2011) Development of edible films and coatings with antimicrobial activity. Food Bioprocess Technol 4(6):849-875

34. Cardenas FC, Giannuzzi L, Zaritzkay NE (2008) Mathematical modelling of microbial growth in ground beef from Argentina. Effect of lactic acid addition, temperature and packaging film. Meat Sci 79:509-520

35. Catarino MD, Alves-Silva JM, Fernandes RP, Gonçalves MJ, Salgueiro LR, Henriques MF, Cardoso SM (2017) Development and performance of whey protein active coatings with Origanum virens essential oils in the quality and shelf life improvement of processed meat products. Food Control 80:273-280

36. Cha DS, Chinnan MS (2004) Biopolymer-based antimicrobial packaging: a review. Crit Rev Food Sci Nutr 44(4):223-237

37. Chi S, Zivanovic S, Penfield MP (2006) Application of chitosan films enriched with oregano essential oil on bolognaactive compounds and sensory attributes. Food Sci Technol Int 12(2):111-117

38. Chillo S, Flores S, Mastromatteo M, Conte A, Gerschenson L, Del NMA (2008) Influence of glycerol and chitosan on tapioca starch-based edible film properties. J Food Eng 88(2):159-168

39. Claudia ARB, Luis ABP, María AG, Miriam NM, Javier SFNZ (2005) Physicochemical and microstructural characterization of films prepared by thermal and cold gelatinization from non-conventional sources of starches. Carbohyd Polym 60(2):235-244

40. Costerton JW, Irvin RT, Cheng KJ (1981) The bacterial glycocalyx in nature and disease. Annu Rev Microbiol 35(1):299-324

41. Cutter CN (2002) Microbial control by packaging: a review. Crit Rev Food Sci Nutr 42:151-161

42. Cutter N (2006) Opportunities for bio-based packaging technologies to improve the quality and safety of fresh and further processed muscle foods. Meat Sci 74:131-142

43. Dalmas F, Cavaille JY, Gauthier C, Chazeau L, Dendievel R (2007) Viscoelastic behavior and electrical properties of flexible nanofiber filled polymer nanocomposites. Influence of processing conditions. Compos Sci Technol 67:829-839

44. Daniels R (1973) Edible coatings and soluble packaging. Food Technol. https://doi.org/10.1002/food.19740180240

45. Dawson LE, Gartner R (1983) Lipid oxidation in mechanically deboned poultry. Food Technol 37(7):112-116

46. De Abreu DP, Losada PP, Maroto J, Cruz JM (2010) Evaluation of the effectiveness of a new active packaging film containing natural antioxidants (from barley husks) that retard lipid damage in frozen Atlantic salmon (Salmo salar L.). Food Res Int 43(5):1277-1282

47. De Moura MR, Aouada FA, Avena-Bustillos RJ, McHugh TH, Krochta JM, Mattoso LHC (2009) Improved barrier and mechanical properties of novel hydroxypropyl methylcellulose edible films with chitosan/tripolyphosphate nanoparticles. J Food Eng 92(4):448-453
48. de W Blackburn C (ed) (2006) Food spoilage microorganisms. Woodhead Publishing, Cambridge

49. Debeaufort F, Voilley A (2009) Lipid-based edible films and coatings. In: Huber KC, Embuscado ME (eds) Edible films and coatings for food applications. Springer, New York, pp 135-168

50. Diab T, Biliaderis CG, Gerasopoulos D, Sfakiotakis E (2001) Physicochemical properties and application of pullulan edible films and coatings in fruit preservation. J Sci Food Agric 81:988-1000

51. Donhowe IG, Fennema ON (1993) The effects of plasticizers on crystallinity, permeability, and mechanical properties of methylcellulose films. J Food Process Preserv 17(4):247-257

52. Durango AM, Soares NFF, Benevides S, Teixera J, Carvalho M, Wobeto C, Andrade NJ (2006) Development and evaluation of an edible antimicrobial film based on yam starch and chitosan. Packag Technol Sci 19:55-59

53. Dutta PK, Tripathi S, Mehrotra GK, Dutta J (2009) Perspectives for chitosan based antimicrobial films in food applications. Food Chem 114(4):1173-1182

54. Ejaz M, Arfat YA, Mulla M, Ahmed J (2018) Zinc oxide nanorods/clove essential oil incorporated Type B gelatin composite films and its applicability for shrimp packaging. Food Packag Shelf Life 15:113-121

55. Elsabee MZ, Abdou ES (2013) Chitosan based edible films and coatings: a review. Mater Sci Eng C 33(4):1819-1841

56. Fabra MJ, Jimenez A, Atares L, Talens P, Chiralt A (2009) Effect of fatty acids and beeswax addition on properties of sodium caseinate dispersions and films. Biomacromolecules 10:1500-1507

57. Fratianni F, Martino LD, Melone A, Feo VD, Coppola R, Nazzaro F (2010) Preservation of chicken breast meat treated with thyme and balm essential oils. J Food Sci 75(8):528-535

58. Friedman M (2006) Antibiotic activities of plant compounds against non-resistant and antibiotic-resistant foodborne human pathogens. In: Cherry JP, Tunick MH, Juneja VK (eds) Advances in microbial food safety, ACS Symposium Series. American Chemical Society, Washington DC, pp 167-183

59. Gallego MG, Gordon MH, Segovia F, Almajano Pablos MP (2016) Gelatine-based antioxidant packaging containing Caesalpinia decapetala and Tara as a coating for ground beef patties. Antioxidants 5(2): 10

60. Garcia MA, Pinotti A, Martino MN, Zaritzky NE (2004) Characterization of composite hydrocolloid films. Carbohyd Polym 56:339-345

61. Gennadios A, Hanna MA, Kurth LB (1997) Application of edible coatings on meats, poultry and seafoods. Food Sci Technol 30(4):337-350

62. Geyer R, Jambeck JR, Law KL (2017) Production, use, and fate of all plastics ever made. Sci Adv. https://doi.org/10.1126/sciad v. 1700782

63. Gimenez B, Moreno S, Lopez CME, Montero P, Gomez GMC (2013) Antioxidant properties of green tea extract incorporated to fish gelatin films after simulated gastrointestinal enzymatic digestion. Food Sci Technol 53:445-451

64. Gómez-Estaca J, De Lacey AL, López-Caballero ME, GómezGuillén MC, Montero P (2010) Biodegradable gelatin-chitosan films incorporated with essential oils as antimicrobial agents for fish preservation. Food Microbiol 27(7):889-896

65. Gómez-Estaca J, Montero P, Giménez B, Gómez-Guillén MC (2007) Effect of functional edible films and high pressure processing on microbial and oxidative spoilage in cold-smoked sardine (Sardina pilchardus). Food Chem 105(2):511-520

66. Gontard N, Duchez C, Cuq JL, Guilbert S (1994) Edible composite films of wheat gluten and lipids: water vapor permeability and other physical properties. Int J Food Sci Technol 29:39-50 
67. Goulas AE, Kontominas MG (2007) Combined effect of light salting, modified atmosphere packaging and oregano essential oil on the shelf-life of sea bream (Sparus aurata): biochemical and sensory attributes. Food Chem 100(1):287-296

68. Govaris A, Solomakos N, Pexara A, Chatzopoulou PS (2010) The antimicrobial effect of oregano essential oil, nisin and their combination against Salmonella enteritidis in minced sheep meat during refrigerated storage. Int J Food Microbiol 137:175-180

69. Griffin DB, Keeton JT, Savell JW, Leu R, Vanderzant C, Cross HR (1987) Physical and sensory characteristics of vacuum packaged beef steaks and roasts treated with an edible acetylated monoglyceride. J Food Prot 50:550-553

70. Guilbert S, Cuq B, Gontard N (1997) Recent innovations in edible and/or biodegradable packaging materials. Food Addit Contam 14(6):741-751

71. Gyawali R, Ibrahim SA (2014) Natural products as antimicrobial agents. Food Control 46:412-429

72. Han J (2002) Protein-based edible films and coatings carrying antimicrobial agents. In: Gennadios A (ed) Protein-based films and coatings. CRC Press, Boca Raton, pp 485-498

73. Han JH, Gennadios A (2005) Edible films and coatings: a review. In: Han J (ed) Innovations in food packaging. Elsevier Science and Technology Books, Amsterdam, pp 239-259

74. Hansen NML, Plackett D (2008) Sustainable films and coatings from hemicelluloses: a review. Biomacromolecules 9(6): 1493-1505

75. He H (2012) Effects of environmental policy on consumption: lessons from the Chinese plastic bag regulation. Environ Dev Econ 17(4):407-431

76. Heinz G, Hautzinger P (2007) Meat processing technology for small-to medium scale producers. FAO of the United Nations Regional Office for Asia and the Pacific, Bangkok

77. Hernandez-Izquierdo VM, Krochta JM (2008) Thermoplastic processing of proteins for film formation-a review. J Food Sci 73(2):30-39

78. Holley RA, Patel D (2005) Improvement in shelf-life and safety of perishable foods by plant essential oils and smoke antimicrobials. Food Microbiol 22:273-292

79. Hong SI, Krochta JM (2006) Oxygen barrier performance of whey-protein-coated plastic films as affected by temperature, relative humidity, base film and protein type. J Food Eng 77:739-745

80. Hong YH, Lim GO, Song KB (2009) Physical properties of Gelidium corneum-gelatin blend films containing grapefruit seed extract or green tea extract and its application in the packaging of pork loins. J Food Sci 74(1):6-10

81. Hopewell J, Dvorak D, Kosior E (2009) Plastics recycling: challenges and opportunities. Philos Trans R Soc B Biol Sci 364(1526):2115-2126

82. Howard LR, Talcott TS, Brenes CH, Villalon B (2000) Changes in phytochemical and antioxidant activity of selected pepper cultivars (Capsicum species) as influenced by maturity. J Agric Food Chem 48:1713-1720

83. Hu J, Wang X, Xiao Z, Bi W (2015) Effect of chitosan nanoparticles loaded with cinnamon essential oil on the quality of chilled pork. LWT Food Sci Technol 63(1):519-526

84. Irais SO, Blanca EGA, Eva MSL, Aldo AR, Eleazar BC, Carlos R (2014) Antimicrobial edible films and coatings for meat and meat products preservation. Sci World J. https://doi. org/10.1155/2014/248935

85. Jan JH, Zhang Y, Buffo R (2005) Surface chemistry of food, packaging and biopolymer materials. In: Han JH (ed) Innovations in food packaging. Elsevier Academic Press, Amsterdam, pp 45-59
86. Jang SA, Shin YJ, Song KB (2011) Effects of rapeseed proteingelatin film containing grapefruit seed extract on 'Maehyang' strawberry quality. Int J Food Sci Technol 46:620-625

87. Janjarasskul T, Krochta JM (2010) Edible packaging materials. Annu Rev Food Sci Technol 1:415-448

88. Jayasena DD, Jo C (2013) Essential oils as potential antimicrobial agents in meat and meat products: a review. Trends Food Sci Technol 34:96-108

89. Jimenez A, Fabra M, Talens P, Chiralt A (2012) Edible and biodegradable starch films: a review. Food Bioprocess Technol 5(6):2058-2076

90. Jimenez A, Fabra MJ, Talens P, Chiralt A (2010) Effect of lipid self-association on the microstructure and physical properties of hydroxypropyl-methylcellulose edible films containing fatty acids. Carbohyd Polym 82(3):585-593

91. Jongjareonrak A, Benjakul S, Visessanguan W, Tanaka M (2008) Antioxidative activity and properties of fish skin gelatin films incorporated with BHT and $\alpha$-tocopherol. Food Hydrocoll 22:449-458

92. Jouki M, Yazdi FT, Mortazavi SA, Koocheki A, Khazaei N (2014) Effect of quince seed mucilage edible films incorporated with oregano or thyme essential oil on shelf life extension of refrigerated rainbow trout fillets. Int J Food Microbiol 174:88-97

93. Kakaei S, Shahbazi Y (2016) Effect of chitosan-gelatin film incorporated with ethanolic red grape seed extract and Ziziphora clinopodioides essential oil on survival of Listeria monocytogenes and chemical, microbial and sensory properties of minced trout fillet. LWT Food Sci Technol 72:432-438

94. Karabagias I, Badeka A, Kontominas MG (2011) Shelf life extension of lamb meat using thyme or oregano essential oils and modified atmosphere packaging. Meat Sci 88:109-116

95. Karbowiak T, Debeaufort F, Voilley A (2007) Influence of thermal process on structure and functional properties of emulsion based edible films. Food Hydrocoll 21:879-888

96. Karimnezhad F, Razavilar V, Anvar A, Dashtgol S, Pilehvar Zavareh A (2019) Combined effect of chitosan-based edible film containing oregano essential oil on the shelf-life extension of fresh chicken meat. J Nutr Food Secur 4(4):236-242

97. Karimnezhad F, Razavilar V, Anvar A, Eskandari S (2017) Study the antimicrobial effects of chitosan-based edible film containing the Trachyspermum ammi essential oil on shelf-life of chicken meat. Microbiol Res. https://doi.org/10.4081/mr.2017.7226

98. Kellner W, Kober W (1954) Possibilities of the use of ethereal oils for room disinfection. Arzneimittel Forschung Drug Res $4: 319-325$

99. Kester JJ, Fennema OR (1986) Edible films and coatings: a review. Food Technol 40:47-59

100. Khare AK, Abraham RJ, Rao V, Babu R, Ruban W (2016) Effect of chitosan coating enriched with cinnamon oil ('Cinnamomum zeylanicum') on storage stability of refrigerated chicken meat nuggets. J Anim Res 6(2):1

101. Khare AK, Abraham RJ, Rao VA, Babu RN (2016) Utilization of carrageenan, citric acid and cinnamon oil as an edible coating of chicken fillets to prolong its shelf life under refrigeration conditions. Vet World 9(2):166

102. Khwaldia K, Arab-Tehrany E, Desobry S (2010) Biopolymer coatings on paper packaging materials. Compr Rev Food Sci Food Saf 9:82-91

103. Kim HW, Jeong JY, Seol KH, Seong PN, Ham JS (2016) Effects of edible films containing procyanidin on the preservation of pork meat during chilled storage. Korean J Food Sci Anim Resour 36(2):230

104. Kodal Coşkun B, Çalikoğlu E, Karagöz Emiroğlu Z, Candoğan K (2014) Antioxidant active packaging with soy edible films and 
oregano or thyme essential oils for oxidative stability of ground beef patties. J Food Qual 37(3):203-212

105. Koide S, Shi J (2007) Microbial and quality evaluation of green peppers stored in biodegradable film packaging. Food Control 18:1121-1125

106. Kristam P, Eswarapragada NM, Bandi ER, Tumati SR (2016) Evaluation of edible polymer coatings enriched with green tea extract on quality of chicken nuggets. Vet World 9(7):685

107. Krochta JM (2002) Protein as raw materials for films and coatings: definitions, current status, and opportunities. In: Gennadios A (ed) Protein-based films and coatings. CRC Press, New York, p 40

108. Krochta JM, De MJC (1997) Edible and biodegradable polymer films: challenges and opportunities. Food Technol 51(2):61-73

109. Krogars K, Heinamaki J, Karjalainen M, Rantanen J, Luukkonen P, Yliruusi J (2003) Development and characterization of aqueous amylose-rich maize starch dispersion for film formation. Eur J Pharm Biopharm 56(2):215-221

110. Ladikos D, Lougovois V (1990) Lipid oxidation in muscle foods: a review. Food Chem 35:295-314

111. Lassoued I, Jridi M, Nasri R, Dammak A, Hajji M, Nasri M, Barkia A (2014) Characteristics and functional properties of gelatin from thornback ray skin obtained by pepsin-aided process in comparison with commercial halal bovine gelatin. Food Hydrocoll 41:309-318

112. Layal K, Charafeddine J, Pascal D, Nour EC (2013) Study of surface interactions between peptides, materials and bacteria for setting up antimicrobial surfaces and active food packaging. $\mathrm{J}$ Mater Environ Sci 4(5):798-821

113. Lee KY, Lee JH, Yang HJ, Song KB (2016) Production and characterization of skate skin gelatin films incorporated with thyme essential oil and their application in chicken tenderloin packaging. Int J Food Sci Technol 51(6):1465-1472

114. Lekjing S (2016) A chitosan-based coating with or without clove oil extends the shelf life of cooked pork sausages in refrigerated storage. Meat Sci 111:192-197

115. Letney LR (1958) January 24, U.S. patent 2819975

116. Liu Z (2005) Edible films and coatings from starch. In: Han JH (ed) Innovations in food packaging. Elsevier Academic Press, London, pp 318-332

117. Lobo V, Patil A, Phatak A, Chandra N (2010) Free radicals, antioxidants and functional foods: impact on human health. Pharmacogn $\operatorname{Rev} 4(8): 118$

118. Longares A, Monahan ED, O'Riordan ED, O'Sullivan M (2004) Physical properties and sensory evaluation of WPI films of varying thickness. Lebensm Wiss Technol 37:545-550

119. Mahdavi V, Hosseini SE, Sharifan A (2017) Effect of edible chitosan film enriched with anise (Pimpinella anisum L.) essential oil on shelf life and quality of the chicken burger. Food Sci Nutr 6(2):269-279

120. Mali S, Groddmann MVE, Garcia MA, Martino MN, Zaritzky NE (2006) Effects of controlled storage on thermal, mechanical and barrier properties of plasticized films from different starch sources. J Food Eng 75:453-460

121. Marsh K, Bugusu B (2007) Food packaging-roles, materials and environmental issues. Food Sci 72(3):39-55

122. Mehdizadeh T, Langroodi AM (2019) Chitosan coatings incorporated with propolis extract and Zataria multiflora Boiss oil for active packaging of chicken breast meat. Int J Biol Macromol 141:401-409

123. Melissa GAV, Mariana AS, Lucielen OS, Marisa MB (2011) Natural-based plasticizers and biopolymer films: a review. Eur Polym J 47(3):254-263

124. Mikkonen KS, Rita H, Helén H, Talja RA, Hyvonen L, Tenkanen M (2007) Effect of polysaccharide structure on mechanical and thermal properties of galactomannan-based films. Biomacromolecules 8:3198-3205

125. Milda EE, Kerry CH (2009) Edible films and coatings for food applications. Springer, Dordrecht

126. Min S, Krochta JM (2005) Inhibition of Penicillium commune by-edible whey protein films incorporating lactoferrin, lactoferrin hydrolysate and lactoperoxidase systems. J Food Sci 70:M87-M94

127. Mohan CC, Babuskin S, Sudharsan K, Aafrin V, Mariyajenita P, Harini K et al (2017) Active compound diffusivity of particle size reduced $S$. aromaticum and $C$. cassia fused starch edible films and the shelf life of mutton (Capra aegagrus hircus) meat. Meat Sci 128:47-59

128. Nerín C, Tovar L, Djenane D, Camo J, Salafranca J, Beltrán JA, Roncalés P (2006) Stabilization of beef meat by new active packaging containing natural antioxidants. J Agric Food Chem 54(20):7840-7846

129. Nguyen-Tri P, Nguyen TA, Carriere P, Ngo Xuan C (2018) Nanocomposite coatings: preparation, characterization, properties, and applications. Int J Corros. https://doi.org/10.1155/2018/4749501

130. Nisa UI, Ashwar BA, Shah A, Gani A, Gani A, Masoodi FA (2015) Development of potato starch based active packaging films loaded with antioxidants and its effect on shelf life of beef. J Food Sci Technol 52(11):7245-7253

131. Nisperos-Carriedo MO (1994) Edible coatings and films based on polysaccharides. In: Krochta JM, Baldwin EA, Nisperos CMO (eds) Edible coatings and films to improve food quality. Technomic Publishing Company, Lancaster, pp 305-335

132. Oussalah M, Caillet S, Salmieri S, Saucier L, Lacroix M (2004) Antimicrobial and antioxidant effects on milk protein-based films containing essential oils for preservation of whole beef muscle. J Agric Food Chem 52(18):5598-5605

133. Ozdemir M, Floros JD (2008) Optimization of edible whey protein films containing preservatives for mechanical and optical properties. J Food Eng 84:116-123

134. Paes SS, Yakimets I, Mitchell JR (2008) Influence of gelatinization process on functional properties of cassava starch films. Food Hydrocoll 22:788-797

135. Pankaj SK, Bueno FC, Misra NN, O’Neill L, Tiwari BK, Bourke P, Cullen PJ (2014) Physicochemical characterization of plasma-treated sodium caseinate film. Food Res Int 66:438-444

136. Park HM, Li X, Jin CZ, Park CY, Cho WJ, Ha CS (2002) Preparation and properties of biodegradable thermoplastic starch/clay hybrids. Macromol Mater Eng 287:553-558

137. Pavlath AE, Orts W (2009) Edible films and coatings: why, what and how? In: Embuscado ME, Huber KC (eds) Edible films and coatings for food applications. Springer Science/Business Media, LLC, New York, pp 1-23

138. Pavli F, Argyri AA, Skandamis P, Nychas GJ, Tassou C, Chorianopoulos N (2019) Antimicrobial activity of oregano essential oil incorporated in sodium alginate edible films: control of Listeria monocytogenes and spoilage in ham slices treated with high pressure processing. Materials 12(22):3726

139. Pearson AM, Gillett TA (2012) Processed meats. Springer, Berlin

140. Pegg RB, Shahidi F (2008) Nitrite curing of meat: the $N$-nitrosamine problem and nitrite alternatives. Wiley, New York

141. Pereda M, Ponce AG, Marcovich NE, Ruseckaite RA, Martucci JF (2011) Chitosan-gelatin composites and bi-layer films with potential antimicrobial activity. Food Hydrocoll 25(5):1372-1381

142. Persico P, Ambrogi V, Carfagna C, Cerruti P, Ferrocino I, Mauriello G (2009) Nanocomposite polymer films containing carvacrol for antimicrobial active packaging. Polym Eng Sci 49(7):1447-1455 
143. Petersen K (2000) Biobased packaging materials for the food industry. Trends Food Sci Technol 10:52-68

144. Pitt JI, Hocking AD (2009) Fresh and perishable foods. In: Fungi and food spoilage. Springer, Boston, pp 383-400

145. PlasticsEurope (2006) An analysis of plastics production, demand and recovery in Europe. http://www.plasticseurope.org/

146. PlasticsEurope (2016) Plastics - the facts 2016: an analysis of European plastics production, demand and waste data

147. Pranoto Y, Salokhe VM, Rakshit SK (2005) Physical and antibacterial properties of alginate-based edible film incorporated with garlic oil. Food Res Int 38:267-272

148. Quesada J, Sendra E, Navarro C, Sayas-Barberá E (2016) Antimicrobial active packaging including chitosan films with Thymus vulgaris $\mathrm{L}$. essential oil for ready-to-eat meat. Foods 5(3):57

149. Raeisi M, Tabaraei A, Hashemi M, Behnampour N (2016) Effect of sodium alginate coating incorporated with nisin, Cinnamomum zeylanicum, and rosemary essential oils on microbial quality of chicken meat and fate of Listeria monocytogenes during refrigeration. Int J Food Microbiol 238:139-145

150. Raeisi M, Tajik H, Aliakbarlu J, Valipour S (2014) Effect of carboxymethyl cellulose edible coating containing Zataria multiflora essential oil and grape seed extract on chemical attributes of rainbow trout meat. Vet Res Forum 5(2):89-93

151. Ramos ÓL, Fernandes JC, Silva SI, Pintado ME, Malcata FX (2011) Edible films and coatings from whey proteins: a review on formulation, and on mechanical and bioactive properties. Crit Rev Food Sci Nutr 52(6):533-552

152. Rojas-Grau MA, Avena-Bustillos RJ, Friedman M, Henika PR, Martin-Belloso O, Mchugh TH (2007) Effects of plant essential oils and oil compounds on mechanical, barrier and antimicrobial properties of alginate-apple puree edible films. J Food Eng 81:634-641

153. Ruan C, Zhang Y, Sun Y, Gao X, Xiong G, Liang J (2019) Effect of sodium alginate and carboxymethyl cellulose edible coating with epigallocatechin gallate on quality and shelf life of fresh pork. Int J Biol Macromol 141:178-184

154. Ruiz-Navajas Y, Viuda-Martos M, Barber X, Sendra E, PerezAlvarez JA, Fernández-López J (2015) Effect of chitosan edible films added with Thymus moroderi and Thymus piperella essential oil on shelf-life of cooked cured ham. J Food Sci Technol 52(10):6493-6501

155. Sabina G, Andrzej L (2013) Development and characterization of composite edible films based on sodium alginate and pectin. J Food Eng 115(4):459-465

156. Sagoo S, Board R, Roller S (2002) Chitosan inhibits growth of spoilage microorganisms in chilled pork products. Food Microbiol 19:175-182

157. Sani MA, Ehsani A, Hashemi M (2017) Whey protein isolate/ cellulose nanofibre/ $\mathrm{TiO}_{2}$ nanoparticle/rosemary essential oil nanocomposite film: its effect on microbial and sensory quality of lamb meat and growth of common foodborne pathogenic bacteria during refrigeration. Int J Food Microbiol 251:8-14

158. Saricaoglu FT, Turhan S (2019) Performance of mechanically deboned chicken meat protein coatings containing thyme or clove essential oil for storage quality improvement of beef sucuks. Meat Sci 158:107912

159. Scetar M, Mia K, Kata G (2010) Trends in meat and meat products packaging — a review. Croat J Food Sci Technol 2(1):32-48

160. Schneide J (1972) June 6, U.S. patent 3667970

161. Sejidov FT, Mansoori Y, Goodarzi N (2005) Esterification reaction using solid heterogeneous acid catalysts under solvent-less condition. J Mol Catal A Chem 240(1-2):186-190

162. Sergio BR, Villalobos CJE, Reyes (2012) Physical, mechanical and antibacterial properties of alginate film: effect of the crosslinking degree and oregano essential oil concentration. J Food Eng 110(2):232-239
163. Seydim AC, Sarikus G (2006) Antimicrobial activity of whey protein based edible films incorporated with oregano, rosemary and garlic essential oils. Food Res Int 39:639-644

164. Sharafati Chaleshtori F, Taghizadeh M, Rafieian-kopaei M, Sharafati-chaleshtori R (2016) Effect of chitosan incorporated with cumin and eucalyptus essential oils as antimicrobial agents on fresh chicken meat. J Food Process Preserv 40(3):396-404

165. Shaw C, Secrist J, Tuomy J (1980) Method of extending the storage life in the frozen state of precooked foods and products produced. U.S. Patent 4196219

166. Shekhar U, Kadama SK, Pankaj B, Brijesh K, Tiwari CPJ, Cullenb D, Colm P, O'Donnell (2015) Development of biopolymerbased gelatin and casein films incorporating brown seaweed Ascophyllum nodosum extract. Food Packag Shelf Life 6:68-74

167. Smith PA, Stewart J, Fyfe L (1998) Antimicrobial properties of plant essential oils and essences against five important foodborne pathogens. Lett Appl Microbiol 26:118-122

168. Sodzi-Tettey NAA (2013) Ageing in an elderly Ghanaian population. A cross sectional study of physiological parameters, FOXO3A genetic variability and oxidative stress. Doctoral dissertation, University of Ghana

169. Solomakos N, Govaris A, Koidis P, Botsoglou N (2008) The antimicrobial effect of thyme essential oil, nisin and their combination against Escherichia coli $\mathrm{O} 157: \mathrm{H} 7$ in minced beef during refrigerated storage. Meat Sci 80:159-166

170. Soni A, Kandeepan G, Mendiratta SK, Shukla V, Kumar A (2016) Development and characterization of essential oils incorporated carrageenan based edible film for packaging of chicken patties. Nutr Food Sci 46(1):82-95

171. Sorbal PJA, Menegalli FC, Hubinger MD, Roques MA (2001) Mechanical, water vapor barrier and thermal properties of gelatin based edible film. Food Hydrocoll 15:423-432

172. Souza VGL, Pires JR, Vieira ÉT, Coelhoso IM, Duarte MP, Fernando AL (2019) Activity of chitosan-montmorillonite bionanocomposites incorporated with rosemary essential oil: from in vitro assays to application in fresh poultry meat. Food Hydrocoll 89:241-252

173. Stiles ME (1991) Modified atmosphere packaging of meat, poultry and their products. In: Modified atmosphere packaging of food. Springer, Boston, pp 118-147

174. Thanh TTT, Yuguchi Y, Mimura M, Yasunaga H, Takano R, Urakawa H (2002) Molecular characteristics and gelling properties of the carrageenan family. Macromol Chem Phys 203:15-23

175. Tleukenov YO, Plotnikov SV, Erdybaeva NK, Pogrebnyak AD (2016). Studying of nanocomposite films' structure and properties obtained by magnetron sputtering. In: IOP Conference Series: Mater Sci Eng, vol 110, no 1. IOP Publishing, p 012004

176. Tongnuanchan P, Benjakul S, Prodpran T (2013) Physico-chemical properties, morphology and antioxidant activity of film from fish skin gelatin incorporated with root essential oils. J Food Eng 117(3):350-360

177. Tosati JV, Messias VC, Carvalho PI, Pollonio MAR, Meireles MAA, Monteiro AR (2017) Antimicrobial effect of edible coating blend based on turmeric starch residue and gelatin applied onto fresh frankfurter sausage. Food Bioprocess Technol 10(12):2165-2175

178. Ugalde ML, de Cezaro AM, Vedovatto F, Paroul N, Steffens J, Valduga E et al (2017) Active starch biopolymeric packaging film for sausages embedded with essential oil of Syzygium aromaticum. J Food Sci Technol 54(7):2171-2175

179. Vital ACP, Guerrero A, de Oliveira Monteschio J, Valero MV, Carvalho CB, de Abreu Filho BA et al (2016) Effect of edible and active coating (with rosemary and oregano essential oils) on beef characteristics and consumer acceptability. PLoS One 11(8):e0160535 
180. Wan V, Ch H, Kim MS, Lee SY (2005) Water vapor permeability and mechanical properties of soy protein isolate edible films composed of different plasticizer combinations. J Food Sci 70:387-391

181. Wang Y, Xia Y, Zhang P, Ye L, Wu L, He S (2017) Physical characterization and pork packaging application of chitosan films incorporated with combined essential oils of cinnamon and ginger. Food Bioprocess Technol 10(3):503-511

182. Warris PD (2010) Meat science: an introductory text. CAB International Publishers, New York

183. Weber CJ, Haugaard V, Festersen R, Bertelsen G (2002) Production and applications of biobased packaging materials for the food industry. Food Addit Contam 19:172-177

184. Wilson AS (1995) Plasticizers: principles and practice. Institute of Materials, London

185. Wu J, Ge S, Liu H, Wang S, Chen S, Wang J et al (2014) Properties and antimicrobial activity of silver carp (Hypophthalmichthys molitrix) skin gelatin-chitosan films incorporated with oregano essential oil for fish preservation. Food Packag Shelf Life 2(1):7-16

186. Yang HJ, Lee JH, Won M, Song KB (2016) Antioxidant activities of distiller dried grains with solubles as protein films containing tea extracts and their application in the packaging of pork meat. Food Chem 196:174-179

187. Yang L, Paulson AT (2000) Mechanical and water vapour barrier properties of edible gellan films. Food Res Int 33:563-570

188. Younes I, Rinaudo M (2015) Chitin and chitosan preparation from marine sources. Structure, properties and applications. Mar Drugs 13(3):1133-1174

189. Zehra K, Emiroglu G, Polat Y, Betul KC, Kezban C (2010) Antimicrobial activity of soy edible films incorporated with thyme and oregano essential oils on fresh ground beef patties. Meat Sci 86(2):283-288

190. Zhang L, Liu A, Wang W, Ye R, Liu Y, Xiao J, Wang K (2017) Characterization of micro emulsion nanofilms based on Tilapia fish skin gelatine and $\mathrm{ZnO}$ nanoparticles incorporated with ginger essential oil: meat packaging application. Int J Food Sci Technol 52(7):1670-1679

Publisher's Note Springer Nature remains neutral with regard to jurisdictional claims in published maps and institutional affiliations. 